\title{
The Present Condition of the Monuments of Egypt and Nubia
}

\section{A. Henry Rhind F.S.A., Lond. And Scot}

To cite this article: A. Henry Rhind F.S.A., Lond. And Scot (1856) The Present Condition of the Monuments of Egypt and Nubia, Archaeological Journal, 13:1, 154-163, DOI: 10.1080/00665983.1856.10851006

To link to this article: http://dx.doi.org/10.1080/00665983.1856.10851006

里 Published online: 10 Jul 2014.

Submit your article to this journal $₫$

Q View related articles $₫$ 
THE PRESENT CONDITION OF THE MONUMENTS OF EGYPT AND NUBLA.

BY A. HENRY RHIND, F.S.A., LOND. AND Scot.

So valuable have been the results derived by modern investigation of the Monuments of Egypt, that it may not be uninteresting to be reminded of the present condition of remains which have occupied so prominent a place in the field of antiquarian research. For my own part, although prepared to find the evidence of the vicissitudes through which they have passed, and of the neglect or destructive cupidity of the Egyptian government, so strongly deprecated as well in official documents ${ }^{\mathrm{1}}$ as by personal remonstrance, still I did not expect the reality which on actual inspection is so painfully apparent. Accustomed as we are in Britain to the desecration and destruction of memorials of the past, there is a lower depth of degradation reserved for the monuments of the ancient Pharoahs - a degradation rendered more intense by the noble aspect of the structures themselves, and by the importance of the facts to be deduced from them. Already, in remote ages, they had suffered from the violence of invading conquerors, and the zeal of iconoclasts whose chisels made sad havoc on the sculptured walls; but much of the sense of indignity which their present appearance suggests, arises from the circumstance that the original character which most of the religious edifices, at least, possessed, as centres of population, descended as was natural, after they themselves had ceased to be venerated, and in many cases even to the present day. Hence it is that, except in those instances where the sand of the desert has done its work unaided, the temples are often choked up or encumbered by the debris of dwellings, which gradually encroaching on their precincts, had been built in and upon them. And hence it is, as no attempt has in recent times been made to rescue them from similar inroads, that ruins of

IDr. Bowring's Parliamentary Report on Egypt and Candia. 
extraordinary interest and magnificence are devoted to the vile purposes of a Fellah village. Thus, at Edfoo, a small colony of men and cattle is established on the top of the half-buried temple, after Dendera, the most perfect in Egypt, and foul streams of manure trickle down its decorated walls. So in like manner at Luxor, squalid hovels are huddled round the splendid columns, many of which cannot be approached at all, and many only by penetrating the filthy intricacies of those miserable dwellings. Nor is this by any means an unusual state of things.

The grandest remains of all, however, those at Karnak, have happily escaped a fate so degrading as a matter of sentiment, and so detrimental as a matter of fact. But even they have not been left quietly to the dealings of the hand of time, and they have suffered from the paltry rapaciousness of government officials, who sought there, as it was their habit to seek too often in similar monuments, materials for building some public work, or for burning into lime. In fact, to such a pitch had this species of spoliation arrived some years ago, that, besides other indications of dissatisfaction, several gentlemen of influence addressed remonstrances on the subject to the then Viceroy, Mohammed Ali. The result was a promise from the Pacha that a different course would be pursued, and, as I am informed, a standing order in consonance with this promise was issued and exists. This, however, has not been strictly attended to ; and it has happened oftener than once that government quarrymen have only been deprived of their prey by subsequent representation to the higher powers. I have not heard that they have of late injured the ruins to any great extent, but it is hinted that this is as much owing to the absence of any demand for puilding materials, as from a desire to abide by the prohibitory ordinance. At all events, in the best point of view, the conduct of the government with respect to the monuments is simply passive; for they may be appropriated by the Fellahs as cattle-pens or pigeon-cotes,-in fact. abused or mutilated in every way not even short of actual demolition, without apparently the slightest interference.

The temples in Nubia are similarly circumstanced to those of Egypt. In like manner some are embedded in mud-built hovels, some nearly overwhelmed by the drifting sand, and even some of those excavated in the rock are partially filled 
up by the restless activity of the same agent. The entrance to Aboo Simbel which was cleared about thirty years ago, is particularly exposed to obstruction, and once more is nearly blocked up. With this exception, that wonderful memorial of the ancient religion is in excellent condition, and would not leave much to be desired were it not for the abominable practices of travellers which have so constantly excited indignation.

It will not, of course, be supposed-and the numerous illustrated works which are everywhere met with, would, without any allusion here, counteract the impression-that many of the ruins on the Nile are not singularly perfect considering their great antiquity, and strikingly noble notwithstanding the disadvantages with which they have to contend. Their substantial workmanship has stoutly defied the influence of three thousand years in a climate whose exquisite equability has rendered resistance more simple; their massive proportions cannot easily be degraded even by the closest contact with the degenerate products of modern misery; and they rise up grand and imposing amid surrounding desolation or among the puny parasites that cluster around them. With respect, also, to some of those of which this may be said, it is perhaps often the case that as regards picturesque effect they sacrifice little by being partially buried and encumbered by masses of débris. But scenic interest is a small part of the character of vestiges so intimately bound up with all that concerns the early history of human civilisation, and which have for that very reason been subjected to such sustained scrutiny. Still, notwithstanding the fruits of this investigation; notwithstanding the earnestness with which they are desired; notwithstanding the vigorous pursuit implied by the despatch of four or five national expeditions, no one ruin of constructive architecture, save that at Dendera, whether in Egypt or Nubia, has been thoroughly cleared of rubbish : nor, with the additional exception of Mohammed Ali having caused the portico of the Temple of Esneh to be excavated during one of his visits, has any attempt deserving of notice been made beyond partial explorations at points of interest. No doubt the labour of disclosing the whole of huge temples to their foundations, which might be productive of general instruction and gratification, rather than of any specific discovery of commensurate brilliancy, could not 
reasonably be expected from unaided private enthusiasm, and is, from its nature and magnitude, an undertaking which, did the country possess an enlightened government, could only be looked for from it. Certainly it was a work not sufficiently inviting, beyond the compass of their resources, and savouring far too much of the principle vos non vobis to recommend itself to the scientific commissions who had museums to fill at home, and were laudably ambitious to secure a higher and less barren fame.

With regard to the tombs, which are so valuable from presenting in infinite diversity the various phases of life, manners, and religious belief, their nature-being excavated in the living rock-has preserved them in a great measure from the chance of being gradually dismembered and utterly swept away like structural buildings. But although it is true their chambers and passages deep in the sides of limestone mountains may last to the end of time, these may still be but as the shadow when the substance is gone; for the more perishable decorations on the walls, which may be regarded as the latter, enjoy no similar immunity. In fact, the deterioration which they have experienced, even of late years, is alarmingly considerable, as they manifestly show, and as I have been assured by those familiar with them at the period when a voyage up the Nile was only undertaken by the zealous few, and who have seen what they are to-day. In certain instances, a good deal of this is owing to dust and other impurities arising from some of the tombs, being, as many were centuries ago, inhabited, or at all events occupied as lumber-stores attached to mud-dwellings in front. For example, one of the most remarkable, that known as the Brickmakers', at Goorneh, where scenes of the most interesting description illustrative of arts and customs are depicted with great precision, is in this condition, and is likewise a nursery for tame pigeons, which resent intrusion by fluttering from side to side, and charging the atmosphere with impalpable dust. $^{2}$ That under these circumstances the paintings on the walls should grow dim is not surprising; and it may be anticipated with regret, that a continuance of this state of things will render them at no distant date hopelessly obscure.

2 Dr. Rolinson found this same tomb filled with an Arab family and their cattle. Biblical Researches in Palestine, \&c. Vol. i., p. 543. 
The splendid Sepulchres of the Kings, situated in a mountain gorge, are not, from their sequestered position, liable to this sort of treatment, but in them as everywherein temples as in tombs-the grand enemy of the sculptures has been the very reputation which demonstrates their value. Unlike the usual course, where increasing interest in any object is followed by increasing care, notoriety has in their case been the death-knell of some and the curse of all. It has been their fortune that hosts of the visitors attracted by their fame, instead of bestowing upon them the cheap tribute of respect, have left traces not unworthy of the followers of Attila or of Genseric. Apart from the violation of good taste, the amount of damage which has been inflicted in this manner can scarcely be believed. Whole tableaux previously uninjured either in outline or in colour, have been sacrificed in the attempt to chip out, perhaps, the head of a figure that excited an ignorant acquisitive desire ; elaborate inscriptions have been ruthlessly mutilated to gain possession of one or two of the characters; while here and there are to be found examples of that species of vulgar humour akin to idiotcy, which exhibits itself in irremediably spoiling a historical document or a work of art, for the sake of producing some grotesque effect. But the most glaring offence arises from the pains which so many have taken to secure lasting ridicule for themselves, by scrawling or chiselling their names in the very midst of the sculptures. So often has this silly and hateful practice been reprobated, that I had no intention to allude to it; only, as a part of the present state of matters which I have ventured to describe, I am compelled to say, with regret, that up to this hour a few names seem to be added in equally objectionable positions to those which already excite derision or contempt. While leaving on ruins so distant a record of their visit that might possibly be their only epitaph, it did not probably occur to men like Bruce and Belzoni to what a disastrous extent it might be in the power of followers to copy their example without the slightest exercise of discretion. It is humiliating, however, to find a scientific body quite recently countenancing this modern folly, by disfiguring the Great Pyramid at Gizeh, and inserting above its entrance, under the sanction of the classical title proskunema, a slab with their names, inscribed to the honour of a northern king, who, among other pedantic and equally appropriate 
hieroglyphical epithets, is designated "the Favourite of Wisdom and History."

In connection with this subject it is impossible not to notice the mode of action pursued by some of the scientific expeditions, and particularly by that from Prussia, under Dr. Lepsius, which spent three years in the country from 1842 to 1845 . Everywhere this body made free use of the hammer and the crowbar; and if half the absent groups in tombs and temples, whose removal is attributed to Dr. Lepsius, were carried off by him, he certainly dealt with the monuments with no sparing hand.

It is of course evident that there can be no fixed rule by which to test the propriety of dismantling ancient ruins and transporting the excised fragments to other lands. What in one case would be highly meritorious, would in another be equally reprehensible, the peculiar circumstances of each being the turning-point. Hence an investigator professing to act in the interests of science can only be guided by a sound discretion. That in the exercise of this discretion Dr. Lepsius saw good grounds for some of his proceedings, may unfortunately be very true; but there certainly is room for a grave difference of opinion with regard to some of his more prominent operations. Take for instance the most magnificent tomb in Egypt, Belzoni's, where, finding every column standing, and the whole in general good order, he overthrew one to secure a portion of it, leaving the remaining half crumbling on the floor. Many, we apprehend, would not undertake to defend the decision of Champollion, who, twenty years before, cut away one or two slabs from the same sepulchre; and certainly the act contrasts most unfavourably with the right feeling and considerate care of another distinguished archæologist, Sir Gardner Wilkinson, and his fellow-workers, who, about the same time, laboriously examined and sketched the figures on the walls by the light of wax candles, rather than injure the paintings with the smoke of torches.

But not only are the dilapidations by Dr. Lepsius of a more violent character, they were accomplished under a very different order of things. They were executed after numerous visitors from all countries had begun to visit Egypt chiefly for the sake of those monuments which he was helping to destroy, and at a time when, by increasing facilities 
of communication, a voyage up the Nile was becoming a matter of so easy achievement, that in such a point of view to bring the ruins piecemeal to Europe might be deemed as advisable as to break off the mouldings from some remarkable gothic edifice in Germany, and deposit them in London or Paris. Nor is it enough to say that the sculptures which Dr. Lepsius removed at such a sacrifice, might have been scribbled over or otherwise ruined by successors like those I have before alluded to. For, first, the alternative was no inevitable sequence; second, in so far as the general aspect of the monuments themselves is concerned, it is of little consequence whether they are mutilated by the crowbars of a scientific commission, or by less learned chisels ; and finally since the skill of the draughtsman and modeller has attained such excellence, the presence in our museums of the actual blocks hewn by the old workmen, is not so indispensable for purposes of scientific research, that whole buildings of matchless interest must be irremediably defaced to procure them, and that they should be deprived of the chance, probably every year now becoming less remote, of being preserved in their original and peculiar positions where their value would be tenfold greater. Neither should it be forgotten that this sort of authoritative demolition, by declaring ipso facto, that the ruins are delivered over to perdition, must have largely tended to encourage the destructive faculties of succeeding visitors, and to countenance the wanton carelessness of others. It also ought to be remembered that, formerly, when Mohammed Ali was urged to save the antiquities, he retaliated by saying, "How can I do so, and why should you ask me, since Europeans themselves are their chief enemies?" And thus, although one well-known investigator before named, Sir Gardner Wilkinson, could and did intercede for them with, as we have already seen from his own conduct, the best title to be heard, another, Champollion, who was also particularly pressing in his solicitations, certainly assumed a curiously inconsistent position when he besought ${ }^{3}$ the Pacha to cherish with religious care those very memorials which he himself had just returned from despoiling.

These considerations seem to show that the propriety of the course pursued by Professor Lepsius was at least highly

${ }^{3}$ Lettres ecrites d'Egypte et de Nubie.-A ppendix. 
questionable. It is to be hoped that he saw other reasons which were adequate in themselves and sufficient to satisfy his judgment; for certainly if he were actuated by no higher motive than to bring home tangible fruits of his mission to fill new galleries at Berlin, his well-earned fame and the liberality of his government in sending forth the expedition will not shelter both from the charge of unjustifiable spoliation. His proceedings have frequently been censured severely, and they have sometimes most unfairly been attributed to personal objects. To accusations of this nature, as unjust as they were invidious, he has thought it necessary to allude by repeating that "we made the selection of the monuments not for ourselves, but, commissioned by our government, for the Royal Museum, therefore for the benefit of science and a public eager after knowledge." 4 Yet this alone would not be enough; the end, we know, cannot always justify the means; and where would this reasoning lead? Antiquarian collections are no doubt admirable institutions, and so rare is it to see any overweening zeal displayed in their management, that no reasonable man would think of squeamishly conjuring up obstacles to their progress. But there are certain limits to their field of operation; and were they to be conducted on principles of refined cupidity akin to those which stimulated Aurelian, as some allege, to sack Palmyra for the purpose of seizing the works of art within its walls, or induced Napoleon to dismantle St. Mark's-were their stores to be augmented at the cost of dilapidating ancient structures in every quarter, without due reference to the circumstances or conditions which might render that course desirable in itself or otherwise,- then we should have seed capable of producing all the fruit of a iresh barbaric irruption, and the world might one day be startled by enormities as glaring as the despatch of an expedition to treat for the removal of the Fountain of Lions from the Alhambra, or to subsidise the Neapolitan government for permission to quarry out the choicest vestiges of Pompeii.

Six hundred and fifty years ago a traveller in Egypt, Abd-el-Lateef, condemning by arguments drawn from reason and philosophy, the ravages which had already commenced, deplores that, while "in former times the kings watched

4 Letters from Egypt and Ethiopia. Note p. 41. Horner's Translation. 
with care over the preservation of these precious remains of the past, in these days the reins have been cast loose to men, and nobody has troubled himself to repress their caprices."5 Of the present century this, as we have seen, could be said as truly as of the XIIIth, with the unfortunate addition, that the rulers were now to be regarded as the most dangerous, because the most sweeping and perserering, delinquents, and that too, unhappily, at a time when the progress of scientific discovery was imparting fresh value to the doomed vestiges, and calling more loudly for their conservation. But this would hardly influence in any great degree a semi-barbarous despotism; and under such a government, careless, yet rapacious, lavish, yet niggardly-served by employés corrupt as those in the East proverbially are, even the medium course of quiescent toleration was little likely to prevail if directly opposed to the fancied exigences of a grasping selfinterest. Many have probably heard of the havoc committed, not earlier than the present generation, by vice-regal authority or consent; and for those who may desire minuter information on the subject, an energetic writer has drawn up a long catalogue of the misdeeds of Mohammed Ali, ${ }^{6}$ with a zeal which cannot be disputed, but with a bitter censoriousness almost indicative of personal resentment.

A mere cessation, if such be really the case-a mere cessation of these wholesale razzias is no doubt an important gain, still the monuments, as has been pointed out, suffer from so many other quarters, that no languid supineness would do much more than protract their deterioration, if not destruction. But surely these noble relics are not to perish so miserably just as they are becoming at once more accessible, better understood, and more generally attractive. Every day brings Egypt, so to say, further within the circle of European nations, and more within the influence of that feeling with which those heirlooms of primeval skill are there universally regarded. Yet I fear it will be vain to hope for spontaneous active supervision on the part of the native government, although the organisation of its inferior departments would afford extraordinary facilities for the work at the most trifling expense. If, however, this were ever undertaken before it is too late, whether under the present

s Relation de l'Egypte, trad. par S. de Sacy,.p. 195.
${ }^{6}$ Gliddon's Appeal to the Antiquaries of Europe. 1841. 
tottering régime, or after great political and territorial changes foreseen on all sides shall have occurred-and especially if by judicious exertions the principal ruins were cleared and exhibited to fair advantage, there would be saved for future ages a heritage such as neither they nor we would willingly lose. And it is perhaps not unworthy of notice that, in the position of affairs, a request from the British or French Government to the Porte, and its vassal the Viceroy, would scarcely be neglected. Nor would it be an ignoble use of the paramount influence in the East which the stirring events of the period have given to the Western States, were they to stretch out a hand to preserve for the admiration of generations to come, the remnants of the greatness of a people to whom are traced the germs of our higher civilisation. 